\title{
Sustaining Life: Rethinking modes of agency in vulnerability
}

\section{Tiffany Page}

\section{Department of Sociology, University of Cambridge, Cambridge, UK}

\begin{abstract}
This article discusses ambivalence in the meaning and attribution of agency, and the role it plays in understanding vulnerability as a concept and condition that is specific to individual bodies. This involves examining agency as an embodied resource that vulnerability might draw upon when bodies endure conditions of uncertainty, detention and exile. The documenting of a partial narrative of an individual who set his body on fire provides an analytic lens through which to investigate the complexity and contextual specificities of vulnerability. The article argues that working with a single modality of agency, resulting from a certain slippage between meanings of agency, political agency and resistance, might result in foreclosing alternative forms of living and sustaining lives. Agency is considered more expansively as a capacity for action that is necessarily mediated through situated capabilities, struggles and desires. The article argues for the need to analyse concepts held within a 'grammar of vulnerability' in order to discuss modalities of agency that capture both activities of resistance, but also other, often unseen, investments in sensory, affective and physical labours required for everyday activities in which individuals sustain their lives.
\end{abstract}

Keywords: vulnerability; agency; endurance; migration; resistance; self-immolation

\section{Introduction}


In this article I draw upon a narrative that I developed on aspects of the life of Leorsin Seemanpillai, a Sri Lankan Tamil who sought refugee status after arriving in Australia in early 2013 on a boat from Indonesia. Seemanpillai set his body on fire, an act commonly referred to as self-immolation, after living in community detention for 18 months without an outcome to his claim for asylum. ${ }^{\text {i }}$ The public account of Seemanpillai's life is both incomplete and inconsistent, pieced together by the media taken from first and second-hand accounts, including stories told by Seemanpillai to friends and work colleagues. I address aspects of that public narrative in this article as a means to think about the lack of cohesiveness and stability to vulnerability as a concept, and as a condition. In particular, I am interested in how an investigation into agency, defined primarily and broadly through the work of Saba Mahmood (2012) as a capacity for action, can help to expand understandings of what vulnerability is and what it does.

First, I will lay the foundations for how vulnerability is being considered and worked with in this article. My purpose in drawing upon the media accounts of Seemanpillai's self-immolation is not primarily tasked with understanding vulnerability in order to find ways to minimise or eliminate it. A key concern that influences my approach is that while vulnerability involves notions of wounding and injury, and because of this, is in some sense a universal condition of living beings, vulnerability is simultaneously shaped by the lived experiences of individuals. It is an experience that is differentially distributed across particular bodies, where these differences matter to ethics and politics. I suggest that this creates a tension that remains within vulnerability studies: how do we theorise vulnerability in ways that do not serve to erase the specificity and unequal distribution of wounding and injury? 
One of the challenges in working with vulnerability is how its conceptualisation, and the methods through which it is examined, might assume a form of conceptual and temporal coherence across cultural, social and historical contexts (Mohanty 1984, 350). The question of whether vulnerability can be thought of outside of the located context in which bodies are forced to endure and live with conditions of precarity, is a vexing one. In response to this concern, this article contributes to my wider project figuring vulnerability as a located concept. This involves understanding how individuals might draw upon different embodied resources in response to particular situated conditions. I am positing that vulnerability is productive (rather than being positive or negative): it is doing something and exists in relation to the bodies, communities, and contexts in which vulnerability is lived with.

I utilise the term 'local' from the work of Chandra Mohanty $(1984 ; 2003)$ who, in the context of critiquing 'western' Eurocentric feminist projects, addresses the tension of addressing the universal and specific in research. Mohanty argues for the use of 'multilayered, contextual analysis to reveal how the particular is often universally significant — without using the universal to erase the particular or positing an unbridgeable gulf between the two terms' $(2003,501)$. In relation to studying vulnerability, I understand this as a possibility in which to think with localities, and to hold on to the tension of both universal and specific forms of wounding. A notion of the local is central to the work of other postcolonial feminist scholars including Lila Abu-Lughod (1990), Veena Das (1996; 2007), Gayatri Gopinath (2010), Lata Mani (1998), and Sunera Thobani (2007). I also situate this work within the broader concerns of feminist, postcolonial and queer scholarship with regards to notions of the everyday (for example, Berlant 2007; Brah 1999; Lewis 2009; Mahmood 2012; Muñoz 2008; Povinelli 2011; and Stewart 2007). I trace the lineage of my analysis to 
many of the concerns and approaches provided by these interdisciplinary fields of research.

It is my contention that the process of locating vulnerability requires a critical consideration of how different elements of vulnerability might be induced, constructed, heightened, reduced, or manipulated 'within particular local contexts' (original italics) (Mohanty 1984, 344). Locality as a concern resists any easy reduction to cause and effect, or being made intelligible through coherent, stable discursive categories of agency, gender, race, cultural practices, or socio-economic status. This means the notion of the local becomes a tool of specification, which holds theoretical categories and concepts, such as agency, to account for their situated politics. Specifically, I argue that localised analyses of the micro level details of lives, which includes an incomplete narrative of Seemanpillai's life, can help to make visible the ways in which vulnerability is unevenly distributed across different bodies, and how vulnerability might be lived with and conditions of precarity endured. Location refers to the specificity of the life of Seemanpillai, but also to the localities in which this work takes place, and the situatedness of my own role in this process. The local operates in ways that are multilayered, and is designed to focus attention on the tensions in this work, but also on the means of analysis that multi-sited localities might offer to cross-cultural research. Therefore, the emphasis on the local leads me to consider the mediated qualities of vulnerability.

Through this understanding, I have come to consider how there might be elements or resources drawn upon by bodies, and held within a 'grammar of vulnerability', which will be discussed in a later section. This is a direct response to my ongoing difficulties in conceptualising vulnerability as a singularity or ontological 
pull on life that impresses upon individuals in the same way irrespective of location, the capacities, desires and obligations placed upon specific bodies, and the conditions in which we might live. I use 'elements or resources' in part as placeholder terms to help in exploring how we might think about the multi-layered, overlapping, and ambivalent, and embodied characteristics of vulnerability that are not necessarily universal or shared. The work of Butler et al. $(2016,1)$ has informed my approach to thinking about vulnerability. They propose that particular embodied activities, such as those involved in resistance, might draw from vulnerability as a resource of that vulnerability. This framing of vulnerability as productive connects to understandings of its articulation as a form of responsiveness to others, and therefore a methodological practice (Page 2017). Judith Butler argues that responsiveness 'is a function and effect of vulnerability — of being open to a history, registering an impression, or having something impressed upon one's understanding' $(2015,149)$. In this article, I focus on the uneven ways vulnerability plays out across different bodies and through responses to our own, and others' vulnerability. This article considers vulnerability as a concept and condition that is differentially experienced and located, where we need to recognise and attend to these differences. In providing an approach that might help to acknowledge located difference in conceptualisations of vulnerability, I ask: what might change if vulnerability was understood through the relations, capacities, and networks in which bodies endure and persist? I am also interested in posing the question more broadly: in researching vulnerability and its lived encounters, how do we account for complexities in agency that are not standardised across different bodies, contexts and conditions?

\section{Leorsin Seemanpillai}


I will now turn to the narrative that locates Leorsin Seemanpillai within this discussion. In 1990 when Seemanpillai was six years old his family fled Sri Lanka to escape violence against Tamils, arriving at a refugee camp in Tamil Nadu, India, where his family has remained for over 25 years. Seemanpillai travelled towards Australia by boat in late 2012, and an Australian Navy plane spotted the vessel. Seemanpillai arrived on 3 January 2013 without a valid visa and sought asylum in the country. After being held in a series of immigration detention centres within Australia, Seemanpillai was released and relocated to Geelong, a city just outside Melbourne. He was granted a temporary bridging visa that allowed him to live in the community and work while awaiting an outcome to his claim for asylum. On the morning of 31 May 2014, almost 18 months after arriving in Australia and while still awaiting an interview and his claim to be processed, Seemanpillai stood in the yard of his home, poured a soft drink bottle containing petrol over his body, and set himself alight. As his body began to burn, Seemanpillai stripped off his clothes and moved from his yard onto the public road beside his house: 'People had heard his screams and seen "a ball of fire" running down the street outside his small orange brick flat' (Marshall 2014). An off-duty nurse who lived several doors down from Seemanpillai saw smoke in the air and came to his aid, taking him to a local business where she poured bottles of water and wrung soaked towels over his body. Seemanpillai fell unconscious and died in hospital the next morning, as a result of suffering full thickness burns to 90 percent of his body. The event of his self-immolation was featured in both local and national Australian media and covered by global media outlets. The family of Seemanpillai, his parents and three siblings who live as 
refugees in Tamil Nadu, India, were not granted temporary visas for Australia to attend and perform last rites at his funeral.

Seemanpillai was the second Sri Lankan in the space of several months to selfimmolate in Australia in 2014. His act was followed by another incident on 20 June 2014 by a Sri Lankan man not named by the media, and the self-immolation of Khodayar Amini on 18 October 2015, a Hazara Afghan who was also on a bridging visa awaiting a decision on his claim for asylum. Seemanpillai's story, that of a young man who sought refuge in another country, is situated within the socio-political relations involving the movement of people from Sri Lanka to Australia. It is influenced by and grounded within specific political unrest and violence with its own complex history and context, which created the need for Seemanpillai to flee one precarious location for another. It is also informed by Australian Government policies on border policing, immigration and protection. It involves understanding the history and politics of immigration policies that create situations where death and self-harm become accepted by-products of closed borders (Whitley 2014).

The time in which Seemanpillai lived in Australia coincided with a significant period of change in the country's immigration policies. Some media reports claim that processing delays and the length of time he waited led to Seemanpillai's death. In November 2012, the Labour party-led Australian Government introduced a 'nonadvantage' principle applied to people who arrived by boat to Australia without visa documents after 13 August 2012 and for all future arrivals, which included Seemanpillai. In practice, it meant that rather than being transferred 'offshore for regional processing' to detention centres on Nauru and Manus Island, Papua New 
Guinea, some people would be processed while living in Australia. However, those processed outside of these offshore detention centres would not have an advantage in either processing time or outcomes. By the end of November 2014, 30,000 asylum seekers were awaiting claims for protection, with 25,000 living on community bridging visas, of which Seemanpillai had been one. At the time the Australian Immigration Minister estimated it would take up to three years to work through the backlog once the temporary protection visa legislation was passed. ${ }^{\text {ii }}$ On 5 December 2014, seven months after Seemanpillai's death, the Australian Parliament passed legislation to introduce a Temporary Protection visa (TPV) valid for up to three years, and a Safe Haven Enterprise visa (SHEV) valid for five years. After that period TPV applicants are only eligible to apply for another TPV or a SHEV. As part of this new legislation the Government stated it was 'committed to not granting Permanent Protection visas to people who arrived illegally and engage Australia's protection obligations. ${ }^{\text {,ii }}$

\section{Reading for resistance}

My interest in understanding agency and the meaning assigned to particular bodily activities, was born from my attempts to make sense of practices and activities of selfharm. I have written elsewhere on the methodological approach and ethical and epistemological concerns of the wider research project in which this work was undertaken. This led me to consider the possibility for vulnerable writing within feminist methodological approaches to research, and to develop the outline of a vulnerable method (Page 2017). The media reported on the news that Seemanpillai had set himself on fire in a suburban street in the city of Geelong in late May 2014. 
There were multiple media accounts of what had happened, video is included, not of Seemanpillai's act but of interviews with friends, there are quotes from Seemanpillai's church pastor, refugee advocates, work colleagues, and his family are interviewed in India. I was struck by wanting to know why Seemanpillai had acted in this way. The media wanted to know too. They asked, what was on Leo's mind? The Minister for Immigration, Scott Morrison, informed media that Seemanpillai's death was 'terrible and tragic accident', and appeared to admonish those who were asking why. Morrison said: 'I frankly don't think anyone is in any position - to draw any conclusions about what is in a person's mind in this situation' (ABC News, 2 June 2014). I did want to know why Seemanpillai had set his body on fire, and what his intention had been.

The archive of online material that I read from Australian and international media began to fan out as I started reading, following the links and tracing both the sketchy details of Seemanpillai's life, and changes in Australian government immigration policies and legislation. I had no means of verifying the accuracy of media reports, nor official government statements, and I was not conducting interviews. What I noticed as my analysis continued, was that the agential energy that welled up in me from my need to do something, to say something about Seemanpillai's death, was simultaneously marking a corresponding depletion in agency that I provided to Seemanpillai. I began to write about Seemanpillai's life in a way that I thought replaced what had been stripped from him in media reports and by Government - it wasn't a terrible and tragic accident that had led to his selfimmolation - it was the conditions of living for 18 months without an outcome to his asylum claim, and it was a protest. Seemanpillai had run from the front yard of his 
house on to a busy street as he burned, which attracted attention, and his action must have meant something. In thinking with my initial response, I suggest the problem of motive or intention is part of this vulnerable encounter. Both my intention to rescue the narrative of Seemanpillai, and the corresponding intention that I needed to impose upon Seemanpillai in order to do this work, are fraught and fractious elements within this process. In the case of self-immolation, questions linger in the air and will not go away: why do people set themselves on fire? Why did Seemanpillai do it? What was on his mind? What caused it? Who or what is responsible? These questions are difficult to ignore. I found this need to know to be a common occurrence in researching self-immolation: 'What combination of cultural, historical, political, and/or religious reasons inspire these acts?' (McGranahan and Litzinger 2012). Yet despite this, many articles and commentaries would conclude that a definitive answer was not possible.

As a method of self-harm, the term 'self-immolation' is used to stabilise and unify acts that remain diverse and ambiguous in intention, meaning and context. On one level, the term self-immolation, when used to refer to a person burning their own body, groups together a range of practices that are both political and deeply personal, and are mediated by historical, cultural and geopolitical conditions, practices, attachments and sensibilities. Certain forms of self-immolation are qualified as political. These particular acts of self-harm by fire are counted during studies of selfimmolation as a method of protest, while others are excluded. For example, Michael Biggs (2005) conducted a frequently cited study of over 500 individual acts of selfimmolation reported by media outlets recorded in the Nexis database between 1963 and 2002. Biggs' proposed an 'ideal type' definition of self-immolation, which 
involves 'an individual intentionally killing himself or herself (or at least gambling with death) on behalf of a collective cause' (173). The framing of intentionality and the weight placed upon its performance in front of an audience is critical to Biggs' definition of a political act. For Biggs, the definition of self-immolation as a protest appears to pivot on a particular 'declared intent to advance a collective cause' (176). As an act of protest, it is 'intended to be public' (173). However, such a definition excludes self-immolations performed in public that 'act on individual—albeit political—grievance', which Biggs argues includes refugees who set their bodies on fire after being refused asylum (176). ${ }^{\text {iv }}$

As an alternative to Biggs' study and definition of self-immolation, Banu Bargu (2014) groups together forms of self-harm, such as hunger strikes, selfinfection, self-mutilation, self-immolation and suicide attacks, as political modalities of self-destruction. Bargu positions these techniques of destruction as having certain elements in common including being self-inflicted, painful, and potentially irreversible (6). Bargu's work centres on 'the death fast' resistance movement of prisoners within Turkish prisons between 2000 and 2007, where a central component of this collective action was a hunger strike. Bargu uses the terms 'weaponization of life' and 'human weapons' to designate the political struggles undertaken by both non-lethal actions and those that were more likely to lead to fatalities. These are directed either towards the self, through actions such as self-immolation, or towards others, through, for example, suicide attacks (14). In her discussion, Bargu suggests that fasting in particular was a means of enacting agency, by prisoners 'taking death into their own hands' $(2010,249)$. A common refrain within discourses of self- 
destruction is the notion of having exhausted alternative options, and how the actions taken seek the restoration of agency.

In the context of the media representation of Seemanpillai's story, I began to consider more broadly what such definitions of self-harm might assume about meanings of agency and the contested, negotiated ways lives are sustained. As a result of researching this context, I became uncertain as to how agency was being utilised within feminist conceptualisations of vulnerability, and whether agency involved primarily the engagement in activities that 'disrupt existing power relations' (Mahmood 2012, 29). In wanting to locate vulnerability in the specificities of individual lives, I began to consider how we might think about a range of actions that are 'indebted to other reasons and histories' that may or may not be knowable, and if these actions might inform understandings of the resources drawn upon by vulnerability (14). Specific to the case of Seemanpillai, how might spectacular acts of self-harm, such self-immolation, make it more difficult to see the complex entanglements of actions and intentions that are wound tightly within a person's discordant desires and capacities? As a response, I suggest at the outset that there might be something productive to be gained by examining the kinds of agential modalities that are required to support and sustain a life. This is because the narrative of Seemanpillai raises questions as to the impact that regimes of detention, whether being detained offshore in processing centres, or living in the community while awaiting outcomes on claims for asylum, have on the physical and emotional health of those who seek refuge in another country. What does the vulnerability mean in this context? How must theoretical conceptions of vulnerability continue to be rethought 
and reimagined when encountering the particularity of historically, culturally and affectively located conditions and lives?

I situate this analysis as being in conversation with feminist concerns as to the relation between actions that expose the body to violence, and methods of resisting and subverting dominant forms of power. I conceive of the use of the body within self-immolation as being connected to, while also, due to its destructive capacities, remaining in tension with, Butler's $(2015,2016)$ more recent work addressing forms of bodily mobilisation within protest and public assembly movements and demonstrations, such as the Occupy movement and the Gezi Park protests in Turkey. While linking to the struggles that Butler describes, which involve bodies acting in concert to demand the end to 'unwilled conditions of bodily exposure', and while acknowledging that 'sometimes deliberately exposing the body to possible harm is part of the very meaning of political resistance', I remain uncertain as to whether this can, either always or on occasion, include self-immolation, especially when the intention of those who burn their bodies remains ambiguous $(2015,126)$. This is because in researching the life of Seemanpillai I became hesitant to suggest that setting fire to one's own body could be understood unequivocally either as a public act of resistance, or as a private act of suicide, or whether its ambiguity might play a central role in the very meanings of such embodied actions.

\section{The obligations of vulnerability}

Responses both to the experience of wounding and the witnessing of forms of injury inflicted upon others have become a provocation, in more recent North American and 
Western European feminist theoretical scholarship, for considering the kinds of obligations that the precarity of life might impose (For example, Butler 2004; 2009; Butler et al. 2016; Butler and Athanasiou 2013; Cavarero 2009; Gilson 2013; Mackenzie et al. 2013; Murphy 2011). I suggest there is an ongoing struggle within feminist theory with the challenges of working with the concept and condition of vulnerability. This involves recognising and analysing its uneven distribution through the operations of different modalities of power, understanding how the eradication of rights and recognition afforded to particular bodies and communities occurs, tracing the impact of the withdrawal of infrastructure and protection, and drawing attention to the erasure of forms of pain and suffering that are inflicted upon and within particular bodies. In doing this work on different lived experiences of vulnerability, the question remains as to how these very real experiences of trauma, loss and the varied impacts of this exposure are to be considered within more conceptual understandings of vulnerability.

I trace my own feminist genealogy for analysing vulnerability to the work of Sunera Thobani (2007) who challenged how the visceral experience of vulnerability can disappear within "western" feminist theoretical discussions when vulnerability shifts to become defined as a bodily and social ontology that is suggestive of its generative potential as a shared condition. Thobani argues that such work ignores imperialist and colonial histories and the responsibilities that remain for the forms of violence that occur within current and former colonial and occupied territories. In doing so, feminist analyses of vulnerability can serve to erase these very histories from discussions of how vulnerability is lived with. In response to the potential for my own work on self-immolation to engage in forms of epistemic violence and 
erasure, I argue that the work of feminist, postcolonial research and critiques of crosscultural and transnational scholarship are instrumental to the framing of political and ethical concerns with vulnerability scholarship (For example: Das 1996; Mahmood 2012; Mani 1998; Mohanty 1984; Smith 1999; Spivak 1984; Visweswaran 1994). Therefore, I suggest that a tension in feminist theory includes how to refigure the imaginary of the singular, autonomous and self-sufficient subject, without ignoring contexts and histories of oppression, or resorting to a notion of dependency that conjures meanings associated with agentless passivity, which requires invoking the need for 'paternalistic' forms of power and protection (Butler 2016). The tension between the need and demand for infrastructure that sustain lives, and its singular presentation as a form of paternalistic state protection and control, is one that exists in the context of Martha Fineman's $(2008,2010,2013)$ work on state responsibility for reducing and eliminating politically induced conditions. Fineman argues for state involvement in legislating for the vulnerable subject in order to deliver and sustain equality across citizens in a way that might be more equitable than current discrimination-based models. However, as Marianne Hirsch and Sarah Bracke (2016; 2016) argue separately, interventions from societal institutions can manifest in the form of a neoliberal trope of self-sufficiency, which has as its goal the building of resilience within vulnerable populations. The intended outcome is to instill within particular populations the necessary tools in which to 'bounce back' from adversity and become autonomous and independent (Bracke 2016). In this way, vulnerability becomes privatised, and vulnerability is moved to the realm of individual responsibility, repositioning suffering as a corresponding personal failure to withstand the very conditions of precarity that mark out and differentially targeting particular populations (Bassel and Emejulu 2017). 
Therefore, a central issue within these wider discussions is the relationship vulnerability has to dependency. This includes social and infrastructure dependencies, where the bodies rely on support in order to endure and survive, but also how this might shift and open the discussion to the social relationality of vulnerability, where action, instead of being autonomous, comes to be comprehended as 'supported action' (Butler 2016). This article attempts to make a contribution to some of these challenges to conceptualising vulnerability. I propose there is much to be offered by working with existing scholarship that is attempting to move vulnerability away from being tightly bound up in binary opposites: that to think with vulnerability as a concept involves evacuating forms of activity and agency (Butler et al., 2016). Butler et al. (2016) specifically address the occlusion of activity as an epistemological and empirical concern in conceptualisations of vulnerability, where the assumed passivity of vulnerability as a condition has made it difficult for the people, objects, materials and environments that have become attached to and represented by such meaning, to be described in terms that are suggestive equally of activity, future imagining, and political mobilisation. As a response, they seek to reconceptualise vulnerability through its relations and fractures with forms of political subjectivity, where vulnerability cannot be unbound from the intricate connection between acting and suffering, between affecting and being affected, and between response and demand. It is this connection between political subjectivity and vulnerability that I wish to consider for the remainder of this article.

\section{Troubling agency}


As discussed above, the challenge of rethinking vulnerability as a site of supported activity has been more recently undertaken by Butler et al. (2016) who seek to depart from structured conventions that have formulated vulnerability as a site of passivity, which can conversely lead to its erasure from the realm of the public. Here agency, and its association with particular forms of activity, plays a key role in the analysis. The discourse of protection and victimisation implies a relation to specific bodily and/or environmental materialities, conceived as sites of inaction, in contrast to the action and agency assumed within authoritarian models of power (1). In particular, Butler's analysis has sought to disrupt the association of vulnerability with a notion of bodily exposure that does not also involve mobilising forces or potential $(2016,14)$. In response to this challenge to refigure vulnerability within forms of activity, Butler et al. examine the possibilities for a relation between vulnerability and political agency through considering how vulnerability might be required as 'one of the conditions for the very possibility of resistance' $(2016,1)$. It is within the context of these recent provocations for rethinking the relation between vulnerability and resistance that I want to extend this discussion to consider more specifically the question of agency in conceptualisations of vulnerability, and its connection to political articulations.

More broadly, I am concerned with whether certain attachments to cohesive, unified and stable concepts, which can be conveyed through the ways in which actions and intentions of others might be assumed to be intelligible to those outside of such an experience, might infer an unspoken relation between vulnerability and a normative subject of action. This has arisen through the specific ambivalence that meanings of self-immolation have within definitions and intentions of actions of self- 
harm, and activities of politics and resistance. As Leticia Sabsay (2016) suggests in thinking vulnerability in resistance, there are differences between 'affirming the political signification' of particular activities and declaring that bodily performativity "may articulate particular political "contents"' (295). In the case of self-immolation, the pressing need to assign intention to actions must also engage with the contingent and discordant methods by which bodies may or may not 'produce political articulations' (295).

In thinking through the ways in which different bodies distinguish themselves and respond to conditions of precarity, Talal Asad contends that understandings of agency can assume there is standardisation across bodies (2000). To illustrate this, Asad argues that even when there are culturally mediated understandings of sickness, disease, and of how people experience and express pain, 'The sick body is often represented no differently from the healthy body in that for both agency is typically regarded as resistance to power' (31). This is telling in terms of how bodies are assumed to function in similar ways, in their access to resources, the restrictions and limitations placed upon them and their responses to conditions in which they live. Therefore, these discussions of agency therefore must include frustration and tired, sick, frail bodies, those with varying abilities, and those for whom agential modalities might be informed by how their bodies operate in unexpected ways, or are restricted in their movement within and through particular spaces. This means talking about activities that reproduce the banal specificities of living with precarity through means that are particular to an individual and are less connected to normative understandings of healthy bodies involved in acts of autonomy and liberation. 
In returning to my concerns in working with materials that document suffering and assume the intention of another person, I came to write about self-immolation, and specifically develop the partial narrative on aspects of Seemanpillai's life, due to what I perceived was the political ambivalence of his act. In beginning to develop a narrative on the life of Seemanpillai I first read into his bodily movement the possibility of resistance. According to sources quoted in media articles, after Seemanpillai set his body on fire he stripped off his clothes and ran from the privacy of his yard onto a street. It was in his activity of moving from the private house to the public street that I saw the potential for viewing Seemanpillai's act as a particular expression or articulation of political agency or protest. It was the shifting movement of his body - and with this what I thought was the displacing of an act of self-harm that occurred within a private dwelling with one that occurred in public - that held my attention. I was looking for causes that would help to explain Seemanpillai's actions, for something that would make his intention, and his act of self-harm, somehow knowable within a recognisable frame of intelligibility. I wanted to know why Seemanpillai had set his body on fire and I kept searching for indications within media that might suggest motivation or expose something of Seemanpillai's intention.

After spending time with Seemanpillai's story, and questioning my own reasons and role in narrating his story, I realised that I wanted to find evidence of his intentions because I felt that Seemanpillai had been denied this possibility of resistance by the media. I wanted Seemanpillai to be resisting the immigration policies of the Australian Government and hoped that his intention, and his heroic resistance, would be exposed and made visible through the materiality of his actions and movement: that Seemanpillai ran into a public street. The news reports used 
language such as 'despair', which denoted an implied passivity, and I wanted to assign a particular agency to Seemanpillai that was active, that read his vulnerability as being mobilised as a political act as he burned his body and proceeded to run. However, in originally positing that Seemanpillai's self-immolation should remain open to the possibility of resistance, and directing my investigation to such a possibility, I found myself becoming more hesitant, and less comfortable in developing such an alternative narration. My need to know why Seemanpillai set himself on fire, and to ascribe meaning to his actions, is connected to wider ethical and political struggles in representing and responding to another person's suffering. I suggest it speaks to anthropologist Ruth Behar's (1996) proposal that the aim of storytelling might not be to present history, but instead to grapple with the impossibility of telling certain stories (176).

In suggesting that the relation between agency and subalternity is a fraught one, Bracke (2016) reminds us that the concept of agency has been frequently associated with the power involved in speaking on behalf of others, with such acts designed either to give or retrieve the voice of the subaltern (848; Spivak 1984). These methods of recognising the agency of the other simultaneously involve, and cannot be separated from, forms of epistemic violence that transpire through the erasure of such voices from the located position in which they occur (Bracke 2016, 848). Bracke draws upon the work of Gayatri Spivak (2005) to argue that attempts to make subaltern 'resistance, and by extension agency' recognisable can lead to 'a certain slippage between agency and resistance' $(2016,848)$. What distinguishes these two terms? Bracke states that the transposing of meanings of agency upon resistance is connected to the paradox of subjection that plays out through Butler's (1997) notion 
of the formation of the subject $(2016,848)$. In Butler's account, agency has dual roles: subject formation requires forms of agency that resist the imposition of power, but within the 'bind or paradox of agency', such power is also needed to sustain 'our agency and existence' (848). Therefore, the ambivalence of agency in its relation to power is necessary to the constitution of the subject.

However, in cautioning against a move to entwine a notion of agency with an emancipatory politics of the self, Mahmood contends that the desire for freedom and any relation that agency might have to subversion and the recoding of norms is not necessarily an innate desire that exists within a person. Instead it is mediated by other capacities and desires that may not be attempting to fulfill a liberatory form of politics (2001, 211). What has been helpful in thinking about the complexity of agency and its interaction with vulnerability is the way Mahmood disrupts the conception of agency as a 'synonym for resistance to relations of domination' by positioning agency more expansively as a 'capacity for action that specific relations of subordination create and enable' (original italics) $(2012,17)$. Mahmood argues that in considering the question of politics, the starting point is firstly an interrogation of the relation between 'the body, self, and moral agency as constituted in different cultural and political locations' (223). This analysis must be conducted without the assumption of there being a particular self-evident model of resistance that exists in relation to agency.

\section{The grammar of vulnerability}

Within and beyond its application in anthropology, Mahmood's (2012) book Politics of Piety on the women's mosque movement in Egypt, and her work in redefining the 
relationship between politics and agency through the 'insistence on inserting questions of embodiment and ethics into the analysis of politics', (ix) is useful for thinking about the kinds of embodied capacities that conceptions of agency require, and the relation between bodies and capacities of self-cultivation (x). Mahmood sets out to differentiate, without prioritising, the task of understanding the meaning of particular embodied practices, from the task of understanding the work that such practices 'perform in the making of subject, in creating life worlds, attachments, and embodied capacities' (xi). In so doing, Mahmood reminds that there are multiple dimensions of practice, and each can engage in complex interactions and engagements with power in relation to the expression and formation of a subject (xi). A key focus for Mahmood is to elucidate further the kinds of 'constructive work different conceptual understandings of a practice accomplish in the making of subjects and the creation of distinct social and political imaginaries' (xii). This analysis led me to consider the work that self-immolation, as an act of self-harm that does not always or intentionally lead to death, might do in the making of particular subjects. This includes those involved in subversion and resistance, and those struggling with sustaining conditions of everyday living, which vary drastically according to geographical, spatial, cultural and historical forces. How might we understand agency and its role in enabling 'embodied capacities and means of subject formation' within conditions of vulnerability (7)?

By suggesting its multiplicity can be realised by paying attention to modalities of human action, Mahmood lays the groundwork for considering the architecture of agency (x). Mahmood pays attention to the necessity for individuals to engage in a range of disciplinary practices connected to agential capacities, desires and struggles 
that contribute to the formation of the subject. She conveys the difficulties in considering agency in its singularity when attempting to understand the complexities and 'radical dependencies' involved in 'both the becoming of the subject and the process of subjection' (Butler 1997, 83). For Mahmood, the emphasis on a singular or uninterrogated form of agency, especially one associated with resistance, ignores 'other modalities of agency whose meaning and effect are not captured within the logic of subversion and resignification of hegemonic terms of discourse' $(2012,153)$. While Mahmood argues that Butler's analysis of agency privileges the elements of agency involved in activities that destabilise, unsettle and involve the potential for norms to be resignified, I propose that Mahmood's analysis is not in opposition to but instead exists in conversation with Butler's discussion of agency. The role of the social, cultural, historical and affective dependencies in Mahmood's proposal to understand agency through open terms of struggle, effort and exertion, which involves neither invoking 'a self-constituting autonomous subject nor subjectivity as a private space of cultivation', can be a means in which to extend Butler's analysis to address a different set of problematics that emerge in thinking about questions of endurance and persistence $(2001,210)$.

For Mahmood, expanding the conception of agency to coexist across both political and ethical concerns connects more closely to a notion of the self as having an ambivalent and discordant relation to particular political commitments $(2012,33)$. In making agency a question of what it means to sustain a life in all its complexity and contradictory elements, the 'constitutive relationship between action and embodiment, resistance and agency, self and authority' is questioned (38). Instead, other kinds of analytical questions about vulnerability and its located conditions, 
embodiment, and sensory impact are opened up productively when 'agency is analyzed in some of its other modalities' (153). This discussion becomes a frame in which to examine how elements or resources of vulnerability might be experienced and encountered through the enactment of different modalities of agency. Mahmood argues for the located ethics and politics of agency, where 'the ability to effect change in the world and in oneself is historically and culturally specific' (14). This means that in maintaining lives that are mediated by a whole host of factors and conditions, 'the meaning and sense of agency cannot be fixed in advance', and instead is connected to, and influenced by 'particular concepts that enable specific modes of being, responsibility, and effectivity' (14). In constructing the narrative on aspects of Seemanpillai's life I began to consider agency as not being singularly directed towards resistance or self-empowerment, but connected to political, cultural and historical forces that impinge upon bodies and subjectivities and direct activities and energies through multiple demands, obligations, and desires. To do this work meant paying attention to the specificities of microcosmic spaces, asking what is required within them and taken from bodies in order to endure within particular lifeworlds, and what this might necessitate from an individual or community. In doing so, vulnerability began to lose its coherence as a universal bodily ontology, and instead came to be interwoven through lives as elements engaged within layers of agential capacities.

One particular mode of burning one's body that has been addressed in feminist theory is sati, the practice of widow burning in India that was formally abolished during British colonial rule in 1829 (Spivak 1988; Mani 1998). Mani argues that colonial discourses on sati informed debates about its practice, and sati, in turn, came 
to be described only from this vantage point. In so doing, the subjectivity and agency of women involved in sati was silenced, erasing from historical documentation decisions made by women to partake in sati or indeed to refuse, as well as instances where women escaped from the funeral pyre. Consequently, the physical suffering that occurred from being burned is largely absent from accounts. Sati became a spectacle of ritualised killing and colonial salvation where the voices and suffering of the women involved disappeared (1998). By focusing on the construction of official narratives and attending to the women at the funeral pyre and the specificities of each case, Mani argues that the colonial rhetoric that portrayed sati as a 'dutiful act of religious volition' was a 'violent fiction' (196). Mani contends that the suffering of women was marginal to colonial debates and the subsequent prohibition of $s a t i .^{\mathrm{v}}$ Mani documents colonial eyewitness accounts of incidents of widow burning and narrative accounts of women's actions and intentions prior to and at the pyre. The representations of women within such discourse are framed as either 'heroines' or 'victims' (162). Mani argues that these 'poles preclude the possibility of a female subjectivity that is shifting, contradictory, inconsistent' and remains contested in accounts where the 'widow escapes or is successfully dissuaded from burning' (162).

This constricted and compressed notion of agency as an either/or negative/positive alternative links to representations of Seemanpillai and the contradictory nature of his subjectivity.$^{\mathrm{vi}}$ In the media, Seemanpillai is portrayed as happy, bright, and alert, he talks about work, gives blood, and leaves his items neatly placed in his locker. Seemanpillai attempts to hang himself, he calls refugee advocates querying whether he will be sent back to Sri Lanka, and calls the friend with whom he journeyed to Australia to ask, 'why are we being punished?' (Marshall, 
2014). Seemanpillai cooks dinner for a friend a week earlier and seems happy. He sees a friend off on a trip two days before he died. An assessment by a mental health caseworker said Seemanpillai showed no evidence of suicidal thoughts when the two spoke on the telephone the day before his self-immolation (Whyte, 2014). When Seemanpillai burned his body he began to run, crying out and removing his clothes. As his subjectivity shifts, Seemanpillai remains neither exclusively a victim nor a hero.

Did Seemanpillai experience a 'change of heart' when he began to burn and experience pain? Was his running and stripping off the clothes that were burning an attempt to save himself, or an expression of the grief he may have felt? The accounts of Seemanpillai's self-immolation do not focus their attention on the 'palpable, visceral, torture' of self-immolation (177). Seemanpillai is represented as an 'agent in pain', to use Mani's phrasing, through the psychological experience of being an asylum seeker, but not through his physical suffering through burning (177). In the accounts of self-immolation, Seemanpillai is described in ways that mirror the accounts of sati that Mani documents, he becomes a body whose response to burning is described as a "ball of fire" running down the street. Seemanpillai's subjectivity disappears through, in Mani's words, 'a type of description which effaces the agency involved in the struggle, rewriting it as a purely physical, animal, reflex' (177). In returning to the question of resistance and its relation to vulnerability and the endurance involved in precarity, the eroding of Seemanpillai's agency in suffering, and what may be read as a struggle with death at the moment that he begins to burn, continues to confuse what resistance might mean in this context. 
Therefore, I propose that the complexity of self-immolation sets up a problem with the relation between resistance and agency and how the silencing of the materiality of pain, and of endurance, can mask activities of struggle and selfmaintenance and their varied agential forms. I propose that Mahmood's notion of modalities of agency can help to unpack the complexity of motivations within activity and has much to offer. It helps to incorporate the inter-subjective weavings and entanglements of discordant and competing capacities, desires, demands and obligations involved in self-making that cannot be separated from experiences of vulnerability. What draws me to Mahmood's work, especially in the context of thinking with vulnerability, is the way that different practices of living can be registered through examining the possibility for alternative and valuable forms of 'human flourishings' outside of the bounds of an insistence on the human subject's refusal to be dominated $(2012,155)$. This can include the ordinary, everyday ways that people attempt to sustain lives while continuing to live with violence (Das 2007). I suggest this is a more expansive way of thinking that can enable an analysis into the influence of situated cultural and historical disciplines and practices that are involved in the way subjectivities are formed and continue to evolve.

This analysis connects to my wider concern of figuring vulnerability as a located, situated concept. Rather proposing an alternative theory of agency that might be productive in discussions of subject formation and resistance, for Mahmood agency remains contingent and interdependent. It might be better thought as 'a complex, relational term, whose senses emerge within semantic and institutional networks that define and make possible particular ways of dealing with people and things' (Asad 2000, 35). Like Mahmood, Asad proposes that the modalities of agency 
employed by embodied subjects will alter depending on the context, conditions, and disciplines in which a person lives, and what the requirements are for living. I interpret this to mean that Asad is not suggesting that agency is relational in the sense of connecting relational elements of subjects together into intelligible forms, or that agential forms of activity can be traced back to underlying causes and effects that are founded upon human action as being synonymous with resistance, which involves a 'questionable vision of history as moral progress' (51). Instead, it is necessary for enquiries to address the limits and constraints as well as possibilities of agential activities, by extending a notion of action that goes beyond 'how the intentionality of particular humans is externalised in acts that 'generate', or 'resist' social structures' (52). Simply put yet complex in its challenge, Asad's focus, which I propose might also encompass many aspects of Mahmood's work, is on examining 'the possibilities for living sanely in a painful world' (52).

This analytic framing holds promise for thinking about vulnerability. In the beginning of this article I offered the question: what might change if vulnerability was understood through the relations, capacities, and networks in which bodies endure and persist? As a contextually situated concept, Mahmood argues that agency, as always contested, needs to be understood 'in terms of the different modalities it takes and the grammar of concepts in which its particular affect, meaning and form resides' (2012, 188). I propose that this analysis, of there being a system or structure of concepts that impinge upon and are dependent upon each other, and which troubles any sense of fixity or cohesive meanings in their enactment, could be adapted and extended to conceive of how understandings of vulnerability might be held within a 'grammar of concepts' (188). This means that in order to understand more clearly what 
vulnerability requires of particular human subjects living with and maintaining lives in conditions of varying precarity, we need to examine how bodies might draw upon particular embodied elements or resources that reside within a grammar of vulnerability. Proposing that the meaning of agency cannot be thought independently, outside of its properties as inhabiting these relational, embodied connections, in turn helps in the gradual unpicking of the interdependent qualities of agency, and shifts the discussion to the concepts in which agency resides. I propose this approach offers new avenues for conceptualising vulnerability: as having access to inter-connected, embodied resources that are residential and responsive. By this I mean they both inhabit, and are responsive to, a multiplicity of physical, affective, cultural, historical and emotional encounters. The activities and capacities of agency, as a resource drawn upon by individuals, might exist within a particular relationship with vulnerability.

\section{Conclusions}

At the outset, I posed the question as to whether there are alternative ways of working with and being worked on by vulnerability that might help begin to account for complexities in agency that are not standardised across different bodies, contexts and conditions. In this article, I have proposed that normative understandings of agency can assume that bodies function in similar ways, irrespective of their access to resources, the restrictions and limitations placed upon them, their physical and emotional capacities, and the responses and decisions people make within conditions in which they live. Following the work of Mahmood (2012; 2001) and Asad (2000) I suggested conceptualising agency as a capacity for action that is focused on a range of 
outcomes, which may vary according to the abilities, needs, obligations and attachments of individuals. These disaggregating elements lay open the vulnerability of a 'western' linear cohesiveness to subjectivity that suggests it is possible to achieve what we set out to do, and that there is a singular modality of agency geared towards autonomy and resistance. It has been my intention in examining agential modalities to illustrate the complexity in how we might think about agency and its nonstandardisation across bodies through particular capacities, struggles and desires (Povinelli 2011, 145). This is part of my broader interest in unstitching the ways that vulnerability is registered and attended to by embodied subjects, within the unspectacular, ongoing time of precarity, which includes the periods spent waiting for outcomes to claims for asylum. I propose that Mahmood's work helps to provide the analytic language to describe the modalities of agency that include tired, or even exhausted bodies, and the difficulty in gaining visibility for certain subjectivities and bodies living within particular conditions of precarity. These modalities of agency, in their heterogeneous and conflicting forms, might reside within a grammar of concepts that holds a range of embodied resources drawn upon by vulnerability. I have argued that is necessary to capture both activities of resistance and the unseen investments in emotional and physical labour required in the agential capacities 'entailed not only in those acts that result in (progressive) change but also those that aim toward continuity, stasis and stability' (Mahmood 2001, 212). As Mahmood suggests, we need to think about 'the kinds of capacities — embodied, rational, technical — these various modalities of agency require', and, in relation to bodies within which and through which such capacities are enacted, 'the conceptions of the body, personhood, and politics these capacities presuppose, enable, and construct' (2012, x). By altering the terms of analysis in this way, it becomes more difficult to predict what people 
might do within particular spaces and times to make a life, to alleviate pain, and to meet their own or someone else's need.

Acknowledgements

I want to acknowledge Leorsin Seemanpillai, his family, and those close to them. Thank you to Yasmin Gunaratnam and Carolyn Pedwell for their continued support. Thank you to the anonymous reviewers for their comments.

${ }^{\mathrm{i}}$ The case of Leorsin Seemanpillai was one of two accounts of individuals who set fire to their own bodies, included in my $\mathrm{PhD}$ research.

ii The source of these statistics on the number of asylum seekers and the lack of processing of claims: Balogh, S. 2014. "Push To End Asylum Claim Uncertainty," The Australian, November, 26. 2014. Last accessed 21 March 2016.

http://www.theaustralian.com.au/national-affairs/immigration/push-to-end-asylumclaim-uncertainty/story-fn9hm1gu-1227134861799

iii Australian Government Department of Immigration and Border Protection Fact Sheet on Safe Haven Enterprise Visas, July 2015. Last accessed 06 February 2018. http://www.refugeecouncil.org.au/wp-content/uploads/2015/08/Fact-Sheet-SafeHaven-Enterprise-visas.pdf

iv Biggs explains his rationale, that "Refugees who kill themselves after being refused asylum, for example, usually act on an individual—albeit political—grievance, without any declared intent to advance a collective cause. Therefore, these cases are excluded" $(2005,176)$. 
${ }^{\mathrm{v}}$ Feminist and postcolonial scholars discussing other gendered and so-called 'harmful cultural practices' have made a similar point, for example, on female genital mutilation (FGM) in colonial and postcolonial contexts. Critical work on 'dowry deaths' in India (often by burning) has also been addressed by authors such as Uma Narayan (1997).

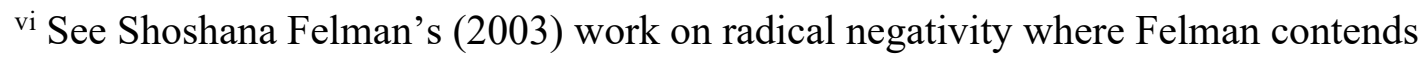
that the negative suggests a productive scandal in proposing the non-opposition of terms and as such is irreducible to the "symmetrical...contrary of the "positive,"” within a normative system (101). For Felman negativity is without positive reference, and escapes the assumption of a 'negative/positive alternative' (104).

\section{References}

ABC News. 2014 "Death of Sri Lankan Asylum Seeker Leorsin Seemanpillai in Geelong A ‘Tragic Accident', Says Scott Morrison,” June, 2. Last accessed 6 February 2018. http://www.abc.net.au/news/2014-06-02/scott-morrison-warnsasylum-seeker-assumptions-geelong/5493656

Abu-Lughod, Lila. 1990. “The Romance of Resistance: Tracing Transforms of Power Through Bedouin Women.” American Anthropologist, 17 (1): 41-55.

Asad, Talal. 2000. "Agency and Pain: An Exploration," Culture and Religion, 1 (1): $29-60$. 
Bassel, Leah and Emejulu, Akwugo. 2017. Minority women and austerity: Survival and resistance in France and Britain. Bristol: Policy Press.

Berlant, Lauren. 2007. "Slow death (sovereignty, obesity, lateral agency)." Critical Inquiry, 33: 754-780.

Bracke, Sarah. 2016. "Is the subaltern resilient? Notes on agency and neoliberal subjects.” Cultural Studies, 30 (5): 839-855.

Brah, Avtar. 1999. The Scent of Memory: Strangers, Our Own, and Others. Feminist Review (61): 4-26.

Butler, Judith, Gambetti, Zeynep, and Sabsay, Leticia. 2016. Vulnerability in Resistance. Durham and London: Duke University Press.

Butler, Judith. 2016. "Rethinking Vulnerability and Resistance.” In Butler, J., Gambetti, Z., and Sabsay, L. 2016. Vulnerability in Resistance. Durham and London: Duke University Press.

Butler, Judith. 2015. Notes Towards a Performative Theory of Assembly. Cambridge, Massachusetts: Harvard University Press.

Butler, Judith. 2009. Frames of War: When is Life Grievable? London: Verso. 
Butler, Judith. 2004. Precarious Life: The Powers of Mourning and Violence.

London: Verso.

Butler, Judith. 1997. The Psychic Life of Power. Stanford: Stanford University Press.

Butler, Judith, and Athanasiou, Athena. 2013. Dispossession: The Performative in the Political. Cambridge: Polity Press.

Cavarero, Adriana. 2009. Horrorism: Naming Contemporary Violence. Trans. W. McCuaig. New York: Columbia University Press.

Das, Veena. 2007. Life and Words: Violence and Descent into the Ordinary. Berkeley: University of California Press.

Das, Veena. 1996. Language and Body: Transactions in the Construction of Pain. Daedalus, 125(1): 67-91.

Felman, Shoshana. 2003. The Scandal Of The Speaking Body: Don Juan With J.L Austin, or Seduction in Two Languages. Trans. C. Porter. Stanford: Stanford University Press.

Gilson, Erinn. 2014. The Ethics of Vulnerability: A Feminist Analysis of Social Life and Practice. New York: Routledge. 
Gopinath, Gayatri. 2010. Archive, Affect, and the Everyday: Queer Diasporic ReVisions. In J. Staiger, A. Czetkovich, A. Reynolds, eds. Political Emotions: New Agendas in Communication. New York: Routledge.

Lewis, Gail. 2009. Birthing Racial Difference. Studies in the Maternal, 1(1): 1-21.

McGranahan, Carole and Litzinger, Ralph. 2012. Self-Immolation as Protest in Tibet. Hot Spots, Cultural Anthropology. Last accessed 6 February 2018. https://culanth.org/fieldsights/93-self-immolation-as-protest-in-tibet

Mackenzie, Catriona, Rogers, Wendy and Dodds, Susan. eds. 2014. Vulnerability: New Essays in Ethics and Feminist Philosophy. Oxford: Oxford University Press.

Mahmood, Saba. 2012. Politics of Piety: The Islamic Revival and the Feminist Subject. Princeton: Princeton University Press.

Mahmood, Saba. 2001. Feminist Theory, Embodiment, and the Docile Agent Some Reflections on the Egyptian Islamic Revival. Cultural Anthropology, 16(2): 202-236.

Mani, Lata. 1998. Contentious Traditions: The Debate On Sati In Colonial India. Berkeley and Los Angeles: University of California Press.

Marshall, Konrad. 2014. “One Man’s Journey To Despair.” The Age, June, 8. Accessed 16 June 2017. http://www.theage.com.au/victoria/one-mans-journey-todespair-20140607-39pvz.html 
Mohanty, Chandra. 2003. ““Under Western Eyes” Revisited: Feminist Solidarity through Anticapitalist Struggles.” Signs, 28(2): 499-535.

Mohanty, Chandra. 1984. "Under Western Eyes: Feminist Scholarship and Colonial Discourses." boundary, 12(3): 333-358.

Muñoz, José. 2009. Cruising Utopia: The Then and There of Queer Futurity. New York: New York University Press.

Murphy, Ann. 2012. Violence and the Philosophical Imaginary. Albany: State University of New York Press.

Narayan, Uma. 1997. Dislocating Cultures: Identities, Traditions, and Third-World Feminism. New York: Routledge.

Page, Tiffany. 2017. Vulnerable Writing as a Feminist Methodological Practice. Feminist Review, 115 (1): 13-29.

Povinelli, Elizabeth. 2011. Economies of Abandonment: Social Belonging and Endurance in Late Liberalism. Durham and London: Duke University Press.

Sabsay, Leticia. 2016. "Permeable Bodies: Vulnerability, Affective Powers, Hegemony,” In Butler, J., Gambetti, Z., and Sabsay, L. 2016. Vulnerability in Resistance. Durham and London: Duke University Press. 
Spivak, Gayatri. 1984. Can the subaltern speak? Proceedings of the Essex conference on the sociology of literature, July 1984. Colchester, UK: University of Essex.

Spivak, Gayatri. 2005. "Scattered speculations on the subaltern and the popular." Postcolonial studies, 8 (4): 475-486.

Stewart, Kathleen. 2007. Ordinary Effects. Durham and London: Duke University Press.

Thobani, Sunera. 2007. "White Wars: Western Feminisms and the 'War On Terror'." Feminist Theory, 8 (2): 169-185.

Visweswaran, Kamala. 1994. Fictions of a Feminist Ethnography. Minneapolis: University of Minnesota Press.

Whitley, Leila. 2014. "More Than A Line: Borders As Embodied Sites.” PhD diss., Goldsmiths, University of London.

Whyte, Sarah. 2014. "Scott Morrison Denies Tamil Asylum Seeker Had Been Showing Suicidal Tendencies," The Sydney Morning Herald, June 2. Last accessed 6 February 2018. http://www.smh.com.au/federal-politics/political-news/scottmorrison-denies-tamil-asylum-seeker-had-been-showing-suicidal-tendencies20140602-39dsb.html\#ixzz3HGSRRK00 